\title{
PENYULUHAN MOTIVASI FINANCE PREUNER PADA MASA PANDEMI
}

\author{
${ }^{1 *}$ Arif Surahman, ${ }^{2}$ Catur Galuh Ratnagung, ${ }^{3}$ Nefo Indra Nizar, \\ ${ }^{4}$ Pancagaluh Ratnasih, ${ }^{\mathbf{5}}$ Edian Fahmy \\ Universitas Pamulang, Tangerang Selatan, Banten, Indonesia \\ Email : " dosen01176@unpam.ac.id
}

Manuskrip: September -2021; Ditinjau: September -2021; Diterima: Oktober -2021; Online: Januari-2022; Diterbitkan: Januari-2022

\begin{abstract}
ABSTRAK
Tujuan umum dari pengabdian masyarakat ini adalah mengedukasi masyarakat mengenai bagaimana cara berinvestasi di pasar modal dengan menggunakan ilmu yang benar, supaya masyarakat dapat terhindar dari cara berinvestasi yang merugikan diakibatkan dari kurangnya pengetahuan tentang bagaimana cara menganilisa sebuah saham dengan benar. Metode yang diaplikasikan pada kegiatan pengabdian ini adalah dengan cara memberikan pembekalan materi atau konsep terlebih dahulu, kemudian di ikuti dengan contoh praktek analisa sebuah saham dengan memakai materi-materi konsep yang telah dipresentasikan. Hasil pengabdian kepada masyarakat ini adalah banyaknya antusiasme dari para peserta mengenai berinvestasi di pasar saham yang diikuti dengan banyaknya pertanyaan dari peserta mengenai bagaimana cara menganalisa investasi dan juga buku-buku tentang analisa saham dan program-program aplikasi yang digunakan untuk menganalisa saham.
\end{abstract}

\section{Kata Kunci: Saham, Analisa, Pengabdian, Masyarakat, Praktek}

\section{PENDAHULUAN}

Selama masa pandemi covid 19 ini banyak orang yang tadinya bekerja di kantor terpaksa harus bekerja dirumah atau istilahnya adalah WFH (Work From Home). Banyak pula orang-orang yang bekerja dirumah ini mencoba untuk memasuki dunia investasi untuk pertamakalinya. Direktur Retail dan Treasury Mandiri Sekuritas, Theodora VN Manik mengatakan, bahwa di masa pandemi, Mandiri sekuritas mencatatkan peningkatan investor baru lebih dari 50\% dibanding periode yang sama tahun lalu. Selain itu, Nilai transaksi harian nasabah retail juga meningkat sekitar $70 \%$ secara tahunan dibandingkan dengan periode yang sama tahun lalu (Sidik, 2020).

Selama kurun waktu periode enam bulan pertama tahun 2020, nasabah baru Mandiri Sekuritas untuk segmen ritel meningkat dari sebelumnya 26.000 nasabah baru menjadi total 145 ribu nasabah. Investor-Investor baru ini banyak yang membeli saham tanpa menggunakan analisa teknikal dan fundamental, serta cenderung beli saham lantaran ikut-ikutan atau istilahnya mereka menggunakan 
strategi follow the herd, berbagai keluhan nasabah dalam berinvestasi saham juga menjadi sorotan, sebab modal investasi nasabah ini menggunakan dana yang berasal dari utang. (Puspitasari, 2021)

Tak sedikit pula investor-investor baru yang terjun ke pasar modal mengalami kerugian karena setelah melakukan pembelian, karena harga saham yang mereka beli tersebut mengalami penurunan. Bahkan pada awal tahun ini seseorang laki-laki berinisial A (27) tewas dengan cara melompat dari lantai 23 Apartemen Ambassador, Karet Kuningan, Jakarta Selatan pada Senin (22/3) siang. Menurut Kapolsek Metro Setiabudi AKBP Yogen Heroes Baruno, korban diduga bunuh diri lantaran mengalami masalah keuangan karena bermain saham (Puspitasari, 2021). Oleh karena itu, para investor-investor baru tersebut butuh diberikan pemahaman dan wawasan yang tepat, supaya mereka bisa mengambil keputusan investasi sesuai dengan profil resiko masing-masing dan terhindar dari kerugian.

Sebenarnya investasi pada saham bukanlah hal yang negatif, bahkan merupakan suatu hal yang positif. Namun, ibarat pergi ke hutan untuk berkemah tanpa pengetahuan dan tanpa perbekalan yang mencukupi, sebuah kegiatan berkemah yang sebenarnya sederhana dapat menyebabkan seseorang kehilangan nyawa. Begitu pula, apabila seseorang berinvestasi di pasar modal tanpa membawa pengetahuan dan perbekalan yang mencukupi. Sebagaimana dikutip dari Priyanti (2021), sebenarnya terdapat delapan keuntungan apabila seseorang terutama generasi milenial melakukan investasi, yaitu:

Pertama, dapat terhindar dari inflasi. Inflasi merupakan hal yang terus terjadi dan tidak dapat dihindari. Uang yang kita miliki saat ini akan mempunyai nilai yang berbeda atau bahkan akan turun nilainya di masa depan. Misalnya, zaman dulu dengan seratus rupiah kita bisa mendapatkan semangkuk bakso. Kini, seratus rupiah bahkan tidak bisa untuk membeli sebutir permen. Dengan melakukan investasi, nilai harta yang anda miliki saat ini akan sejalan dengan naik/turunnya inflasi.

Kedua, menambah sumber penghasilan. Investasi tidaklah sama seperti menabung yang hanya membiarkan uang mengendap di bank. Apabila anda berinvestasi maka nilai uang yang dimiliki akan bertambah karena adanya perputaran uang atau pertumbuhan nilai. Misalnya dalam investasi di Surat Berharga Negara (SBN), uang yang diinvestasikan akan menjadi modal negara untuk pembangunan. Jika negara makin maju, kita sebagai investor juga akan mendapatkan keuntungan sesuai dengan kesepakatan pembagian keuntungan atau kupon yang ditetapkan.

Ketiga, mewujudkan tujuan keuangan. Kalau misalkan kita memiliki tujuan keuangan tertentu, maka pasti kita juga perlu memiliki instrumen untuk mencapainya. Investasi adalah instrumen atau kendaraan yang akan mengantar ke tujuan keuangan tersebut. Seperti sudah dibahas sebelumnya, investasi adalah penghasilan tambahan yang juga akan mengikuti inflasi. Karena itu, kita dapat menghitung dan memperkirakan berapa uang yang akan didapatkan untuk mencapai tujuan di masa depan.

Keempat, menjadikan uang produktif. Dengan berinvestasi yang produktif bukan hanya diri kita yang bekerja tetapi juga uang. Dalam kata lain, kita dapat 
melakukan kegiatan yang kita sukai dengan maksimal tanpa harus pusing dengan kondisi keuangan.

Kelima, memperkecil risiko terlilit utang. Berinvestasi mengharuskan kita menyisihkan sebagian pendapatan. Tentunya hal ini akan menumbuhkan perilaku berhemat. Kebiasaan berhemat akan menjadikan kita selalu merasa aman dan cukup dan apabila kita memerlukan uang tersebut untuk keadaan darurat, kita selalu bisa mengeluarkannya dari investasi kita.

Keenam, persiapan dana pensiun. Untuk mengumpulkan dana pensiun diperlukan waktu yang panjang. Selain itu, kita juga pasti tidak mau bekerja selamanya. Apabila kita berinvestasi dari sejak muda, maka ketika tua nanti kita hanya akan tinggal menikmati buah dari usaha kita tersebut.

Ketujuh, bersifat pengelolaan dana jangka panjang. Investasi bersifat jangka panjang, sehingga hasilnya tidak bisa langsung dilihat keesokan hari. Masyarakat banyak yang memiliki pola pikir yang salah dengan menganggap bahwa investasi tujuannya adalah jangka pendek. Untuk mencapai hasil investasi yang memuaskan diperlukan waktu dan proses dan hal itu merupakan bagian dari perjalanan investasi. Jadi apabila investasi dilakukan dari sejak muda, maka pengalaman dan ilmu yang diraih akan semakin banyak seiring dengan waktu.

Kedelapan, mempersiapkan kehidupan berumah tangga. Investasi dapat membantu membangun keluarga di masa depan. Terlebih, ketika menikah semua kebutuhan akan bertambah, terutama jika sudah memiliki anak. Investasi sejak sebelum menikah akan meminimalisasir kekhawatiran tentang biaya-biaya, seperti dana pendidikan, biaya hidup, beli rumah, dan sebagainya.

Walaupun berinvestasi pada pasar modal merupakan suatu hal yang menarik, namun kegiatan tersebut juga harus didukung dengan pengetahuan dan pengalaman. Oleh karena itu, perlu dilakukan penyuluhan untuk memberikan edukasi kepada masyarakat yang baru saja mencoba-coba menjadi investor dadakan di pasar modal.

\section{METODE}

Untuk menjamin kefektifan kegiatan pengabdian pada masyarakat, maka kegiatan ini akan dibagi kedalam beberapa tahapan dengan metode yang berbedabeda. Kegiatan pengabdian ini akan dibagi dengan beberapa tahapan, yaitu;

1. Pemberian materi tentang, analisa teknikal dan fundamental dalam pasar modal dan lain-lain.
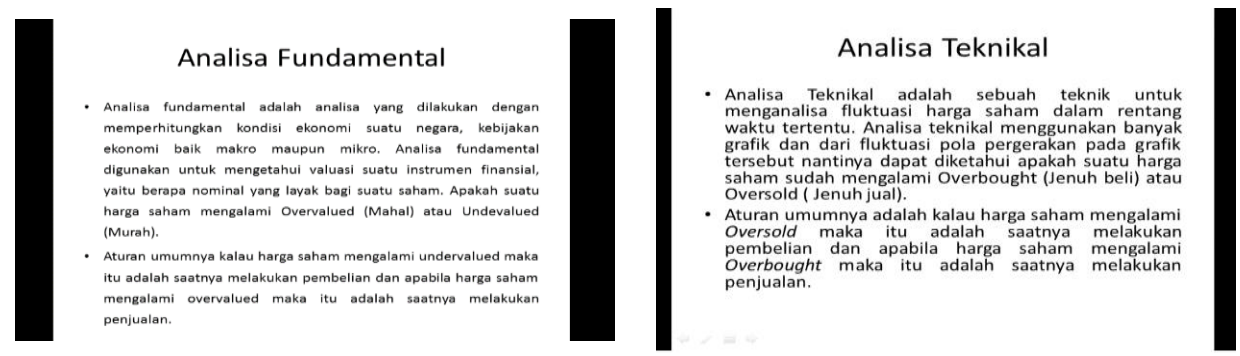

Gambar 1. Materi analisa Fundamental

Gambar 2. Materi PPT analisa Teknikal 
2. Pemberian penyuluhan mengapa kita perlu melakukan investasi

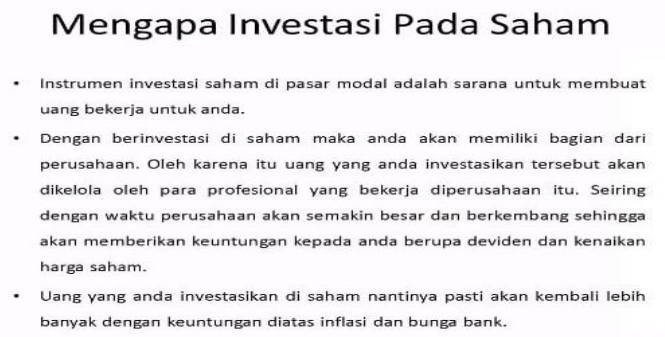

Gambar 3. Pelatihan Mengapa Investasi

3. Berikutnya adalah praktik melakukan analisa investasi saham dengan menggunakan Chart Nexus.

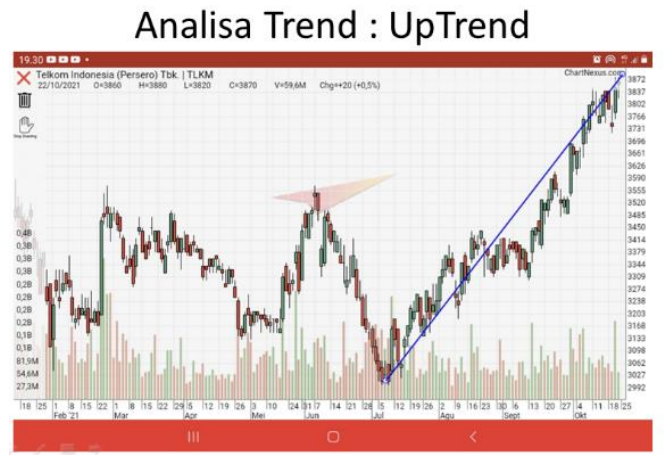

Gambar 4. Menganlisa Uptrend

4. Ilmu pengetahuan dan teknologi (iptek) yang kemudian ditransfer kepada mitra dalam kegiatan ini adalah teknik atau metode/cara menganalisa dan melakukan investasi saham di pasar modal dengan menggunakan trading platform dari PT. Indo Premier Online Trading.

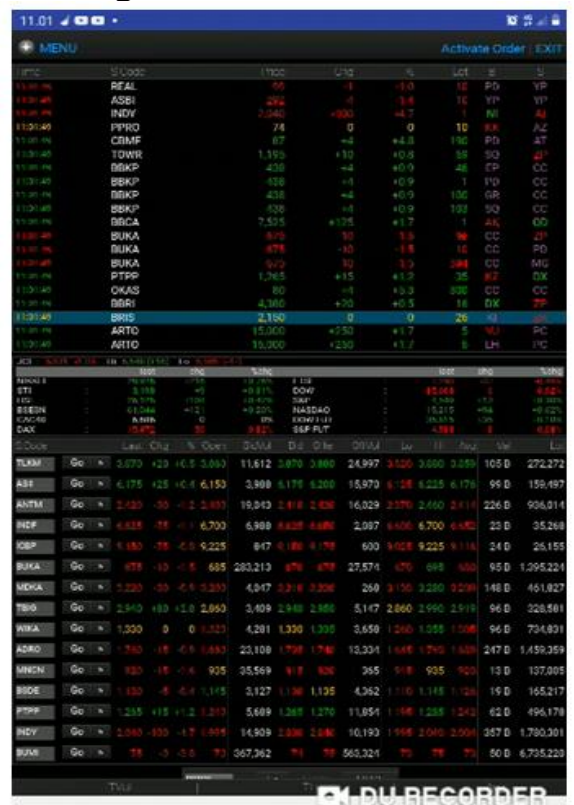

Gambar 5. Platform IPOT 


\section{HASIL DAN PEMBAHASAN}

Pelatihan ini dilaksanakan menggunakan media Zoom dan telah berhasil dengan baik dalam mengedukasi masyarakat peserta tentang investasi di pasar modal. Banyak pertanyaan dari peserta mengenai bagaimana cara memulai investasi di pasar modal dan buku-buku apa yang bisa dibaca untuk memperdalam pemahaman tentang pasar modal. Selain itu, peserta juga antusias tentang program aplikasi Chart Nexus yang diperkenalkan pada acara ini. Beberapa peserta bahkan ingin langsung mendaftar untuk dapat segera melakukan investasi saham

\section{KESIMPULAN}

Dunia investasi saham masih belum banyak menyentuh masyarakat. Padahal dengan melakukan investasi, masyarakat dapat menjadi lebih sejahtera dan makmur. Selain itu, karena masih minimnya tentang ilmu pengetahuan investasi akibatnya banyak orang-orang yang melakukan investasi secara serampangan dan mengakibatkan kerugian, sehingga akibat dari hal itu memperburuk citra melakukan investasi dipasar modal.

Pendidikan investasi dikalangan masyarakat masih perlu terus disosialisasikan. Inklusi keuangan terutama dalam hal investasi saham masih perlu mendapatkan perhatian yang besar baik dari akademisi maupun dari para pengambil kebijakan, terutama dari Badan Pengawas Pasar Modal bidang edukasi.

\section{DAFTAR PUSTAKA}

Andrew, V. \&. (2014). Hubungan Faktor Demografi dan Pengetahuan Keuangan Dengan Perilaku Keuangan Karyawan Swasta di Surabaya. . Finesta.

Bachrudin, E. A. (2016). Pengaruh Pengetahuan Keuangan dan Faktor Demografi Terhadap Perencanaan Keuangan Keluarga. . Sekolah Tinggi Ilmu Ekonomi Perbanas.

Dewi, K. H. (2021, 05 27). https://www.bareksa.com. Diambil kembali dari https://www.bareksa.com/berita/belajar-investasi:

https://www.bareksa.com/berita/belajar-investasi/2021-05-27/8-alasanmengapa-generasi-milenial-harus-investasi

Sunarsi, D. (2018). Pengaruh Motivasi Dan Disiplin Terhadap Produktivitas Kerja Karyawan Pada PT. Nadi Suwarna Bumi. Jurnal Semarak, 1(1), 66-82.

Krishna, A. S. (2007). Analisis Tingkat Literasi Keuangan Di Kalangan Mahasiswa dan Faktor-Faktor yang Mempengaruhinya (Survey Pada Mahasiswa Universitas Pendidikan Indonesia). Academia.Edu.

Kristianti, L. S., et al. (2021). Pengaruh Motivasi Dan Disiplin Kerja Terhadap Kinerja Pegawai Pada Dinas Pariwisata Purwakarta. Jurnal Ilmiah PERKUSI, 1(1), 101-109.

Lukmanto, R. (2014). Studi Deskriptif Persepsi Mahasiswa tentang Perencanaan Keuangan Mahasiswa Di Surabaya. . CALYPTRA : Jurnal Ilmiah Mahasiswa Universitas Surabaya.

Orton, L. (2007). Financial Literacy: Lessons from International Experience. . Canadian Policy Research Networks. 
Puspitasari, I. (2021, 03 24). https://investasi.kontan.co.id. Diambil kembali dari https://investasi.kontan.co.id: https://investasi.kontan.co.id/news/jumlahinvestor-baru-pasar-modal-melonjak-edukasi-jadi-krusial.

Sidik, S. (2021, 10 23). https://www.cnbcindonesia.com. Diambil kembali dari https://www.cnbcindonesia.com:

https://www.cnbcindonesia.com/market/20201023134938-17-

196606/jangan-kaget-selama-pandemi-banyak-yang-jadi-investor-saham

Sina, P. G. (2014). Tipe Kepribadian Dalam Personal Finance. Jibeka.

Wijayanti, Grisvia, a., \& Farida, R. .. ((2016)). Pengaruh Jenis Kelamin, Ipk, Dan Semester Terhadap Literasi Keuangan Mahasiswa Prodi S1 Ekonomi Pembangunan Universitas Negeri Malang. JPE. 